\title{
ISOLASI DAN ELUSIDASI SENYAWA ALKALOID DALAM BIJI MAHONI (Swietenia mahagoni Jacq)
}

\author{
Mamay Maslahat ${ }^{1}$, Helen Lusiana ${ }^{2}$ dan Obie Farobie ${ }^{3}$ \\ Jurusan Kimia, Universitas Nusa Bangsa \\ ${ }^{1} \mathrm{Jl}$. KH. Soleh Iskandar KM 4, Cimanggu, Bogor 16166, Indonesia \\ ${ }^{2}$ SMA 3 Jekan Raya, Palangkaraya 73111, Indonesia \\ ${ }^{3}$ Pusat Penelitian Surfaktan dan Bioenergi, LPPM-IPB \\ Jl. Padjajaran No.1, Kampus IPB Baranangsiang, Bogor, Indonesia \\ Telp/Fax : 08128618243 \\ Email: maykulsum@yahoo.co.id
}

\section{ABSTRACT \\ Isolation and Structure Elucidation of Alkaloid Compounds of Mahoni Seed (Swietenia mahagoni Jacq)}

\begin{abstract}
Along with rising of the term "back to nature", many people have been using traditionally medicinal plants to overcome variety of diseases. Swietenia mahagoni Jacq seeds have potency to treat various diseases including high blood diseases, diabetes, rheumatism, fever, colds, and eczema. This study aimed to isolate and identify the alkaloid compounds found in mahogany seeds (Swietenia mahagoni Jacq). This research was conducted in 3 stages, namely the sample extraction by using methanol and acetic acid, determining the best eluent by using thin-layer chromatography and column chromatography and characterization of compounds by using UV, FTIR, ${ }^{1} \mathrm{H}$ NMR and ${ }^{13} \mathrm{C} N M R$ spectrophotometer. The best eluent from this research was chloroform : methanol with ratio of 90:10 and 95:5. Result of phytochemical test with Mayer and Dragendorf reagent showed that crude extract of mahoni contain alkaloid compound. Results of structure elucidation with UV, FTIR, ${ }^{l} \mathrm{H}$ $N M R$, and ${ }^{13} \mathrm{C}$ was assumed that alkaloid compound contained in mahoni was 3,6,7-trimethoxy-4-methyl-1,2,3,4tetrahydroisoquinoline.
\end{abstract}

Keywords : alkaloid compounds, Swietenia mahagoni Jacq, structure elucidation, chromatoghraphy

\begin{abstract}
ABSTRAK
Seiring dengan meningkatnya semangat "back to nature ", banyak orang telah menggunakan tanaman obat tradisional untuk mengatasi berbagai penyakit. Biji Swietenia mahagoni Jacq berpotensi untuk mengobati berbagai penyakit termasuk penyakit darah tinggi, diabetes, rematik, demam, pilek, dan eksim. Penelitian ini bertujuan untuk mengisolasi dan mengidentifikasi senyawa alkaloid yang terdapat dalam biji mahoni (Swietenia mahagoni Jacq). Penelitian ini dilakukan dalam 3 tahap, yaitu ekstraksi sampel dengan menggunakan metanol dan asam asetat, menentukan eluen terbaik dengan menggunakan kromatografi lapis tipis dan kromatografi kolom, dan karakterisasi senyawa dengan menggunakan instrumen spektrofotometer UV, FTIR, 1H NMR dan 13C NMR, dan GC-MS. Eluen terbaik dari penelitian ini adalah kloroform: metanol dengan rasio 90:10 dan 95:5. Hasil uji fitokimia dengan pereaksi Mayer dan Dragendorf menunjukkan bahwa ekstrak kasar biji mahoni mengandung senyawa alkaloid. Hasil elusidasi struktur molekul diduga bahwa senyawa alkaloid yang terkandung dalam biji mahoni (Swietenia mahagoni Jacq) adalah 3,6,7-trimetoksi-4-metil-1,2,3,4-tetrahydroisoquinoline.
\end{abstract}

Keywords : senyawa alkaloid, biji mahagoni Jacq, struktur elusidati, kromatografi

\section{PENDAHULUAN}

Tanaman merupakan gudang bahan kimia terkaya. Beribu - ribu senyawa kimia terkandung di dalam tanaman namun hingga kini fungsi dan perannya masih belum terungkap seluruhnya. Senyawa - senyawa kimia tersebut memiliki bioaktivitas yang bermacam - macam sehingga dapat dimanfaatkan sebagai bahan baku obat dalam industri farmasi, pembuatan pestisida alami dan sebagai hormon pada pertumbuhan tanaman. Salah satu aktivitas 
dari senyawa kimia tersebut adalah sebagai antikanker yang dapat menghambat pertumbuhan sel kanker atau bahkan dapat membunuh sel kanker.

Swietenia mahagoni Jacq. atau mahoni berdaun kecil merupakan tanaman tropis yang termasuk famili Maliaceae. Di Indonesia, terdapat tiga spesies pohon mahoni, yaitu S. macrophyla King (mahoni berdaun lebar), S. mahagoni Jacq. (mahoni berdaun kecil) dan Swietenia sp.

Selama ini pohon mahoni dikenal sebagai tanaman yang menghasilkan kayu sebagai bahan pembuat furniture dan perabot rumah tangga serta banyak ditanam di pinggir jalan sebagai pohon pelindung. Biji mahoni memiliki potensi sebagai bahan obat. Menurut Syamsuhidayat dan Hutapea, biji mahoni (S. mahagoni Jacq) ternyata dapat digunakan untuk mengobati berbagai penyakit diantaranya penyakit darah tinggi, kencing manis, rematik, demam, masuk angin, eksim dan dapat menambah nafsu makan. Biji mahoni juga berpotensi untuk mengobati penyakit kanker.

Kandungan kimia mahoni dipengaruhi oleh iklim dan cuaca serta habitat masing - masing mahoni. Ekstrak biji mahoni (Swietenia mahagoni Jacq.) mengandung flavonoid dan saponin yang diekstraksi dengan metanol. Menurut Supriyatna tanaman mahoni mengandung senyawa ester metil klorogenat dan asam klorogenat. Biji mahagoni Afrika yang diekstraksi dengan etanol dan diekstraksi partisi dengan etil asetat mengandung senyawa tetranotriterpenoid (Govindachari, R. R., Kumari G. N. K, 1998). Ekstrak etanol dari biji Swietenia sp. mengandung alkaloid, terpenoid, dan flavonoid. Menurut Sianturi kandungan metabolit sekunder pada biji mahoni adalah alkaloid, flavonoid, steroid, terpenoid, dan saponin.

Penelitian terdahulu telah berhasil melakukan isolasi dan fraksinasi senyawa bioaktif dari biji mahoni (Swietenia mahagoni Jacq). Haryanti telah berhasil mengisolasi senyawa antibakteri dari biji mahoni (S. mahagoni Jacq). Putri telah berhasil mengisolasi fraksi aktif dari biji mahoni yang bersifat toksik terhadap larva udang Artemia salina Leach dan dapat menghambat pertumbuhan Sacharomyces cerevisiae sebagai uji awal terhadap senyawa anti kanker.

Penelitian ini bertujuan mengisolasi dan mengidentifikasi senyawa alkaloid yang terdapat pada biji mahoni (Swietenia mahagoni Jacq).

\section{PENELITIAN}

\section{Bahan}

Bahan - bahan yang digunakan adalah biji Swietenia mahagoni Jacq. yang diperoleh dari Laboratorium Budidaya Hutan, kloroform, metanol, n-heksana, asam asetat 10\%, ammonia $10 \%$, petroleum benzena, lempeng kromatografi lapis tipis (KLT) silika gel G 60 F254 $(20 \times 20 \mathrm{~cm})$, dan pereaksi Dragendorf.

\section{Peralatan}

Peralatan yang digunakan adalah alat - alat gelas, soxhlet, hot plate, penangas air, kondensor, lempeng uji, kolom kromatografi, instrumen spektrofotometer UV-Vis, spektrofoto meter infra red, gas kromatografi spektra massa (GC-MS) dan NMR.

\section{Prosedur}

\section{Penyiapan Sampel}

Sebanyak 200 gram biji mahoni dikeringkan dengan cara diangin udarakan untuk mengurangi kandungan air. Setelah itu, biji mahoni tersebut dihaluskan dengan blender untuk memperbesar luas permukaan. Sebanyak $30 \mathrm{~g}$ serbuk biji mahoni kemudian diekstrasi dengan soxhlet menggunakan petroleum benzena $300 \mathrm{ml}$ selama 8 jam. Ekstrak petroleum benzena diuapkan sampai semua pelarut hilang. Ampas hasil ekstraksi dibebaskan dari pelarutnya dengan cara diangin - udarakan. 


\section{Ekstraksi Sampel}

Sebanyak 25 g serbuk biji mahoni bebas lemak diekstraksi dengan metode refluks menggunakan metanol sebanyak $125 \mathrm{ml}$ dan asam asetat $10 \%$ sebanyak 25 $\mathrm{ml}$ pada suhu $60^{\circ} \mathrm{C}$ selama 2 jam. Campuran yang terbentuk disaring kemudian ditambahkan larutan ammonia $10 \%$ sebanyak $2,5 \mathrm{ml}$ lalu disaring kembali. Filtrat didinginkan lalu dipekatkan dengan rotarievaporator. Uji kualitatif alkaloid dilakukan terhadap ekstrak pekat dengan pereaksi Dragendorf. Uji positif ditunjukan dengan terbentuknya warna jingga.

\section{Analisis Kromatografi Lapis Tipis}

Pelat kromatografi lapis tipis yang siap digunakan dipotong dengan ukuran $10 \times 1 \mathrm{~cm}$. Setelah itu, ekstrak hasil rotarievaporator dispotkan pada pelat KLT silika gel G 60 F254 lalu dimasukkan ke dalam bejana yang sebelumnya dijenuhkan dengan beberapa eluen. Jenis eluen yang digunakan adalah kloroform dan metanol dengan perbandingan $90: 10,95: 5,75$ : $25,50: 50,35: 65,25: 75,5: 95$. Komposisi eluen yang terbaik digunakan untuk memisahkan senyawa dalam biji mahoni pada kromatografi kolom.

\section{Analisis dengan Kromatografi Kolom}

Ekstrak hasil evaporasi dilarutkan menggunakan pelarut kloroform lalu dimasukkan ke dalam kolom yang berisi fase diam silika gel. Fraksinasi dilakukan dengan teknik gradien elusi menggunakan pereaksi n-heksana (100\%), n-heksana : kloroform (50:50); kloroform : metanol (95: 5) dan kloroform : metanol (80:20). Fraksi yang dihasilkan ditampung dalam tabung reaksi lalu diuji dengan KLT. Eluen yang memiliki Rf yang sama digabungkan sebagai satu fraksi lalu dipekatkan dengan rotarievaporator untuk keperluan elusidasi.
Analisis dengan Spektrofotometer UVVIS, IR, NMR ${ }^{1} \mathrm{H}$ dan ${ }^{13} \mathrm{C}$

Fraksi yang terbaik dari hasil kromatografi kolom dipekatkan dengan rotarievaporator. Ekstrak yang dihasilkan kemudian dimurnikan dengan rekristalisasi menggunakan pelarut diklorometana dan heksana dengan perbandingan $2: 1$ sambil dipanaskan pada penangas air. Kristal yang dihasilkan kemudian dianalisis dengan spektrofotometer UV-VIS, IR, NMR ${ }^{1} \mathrm{H}$ dan ${ }^{13} \mathrm{C}$.

\section{HASIL DAN PEMBAHASAN}

\section{Pencirian Sampel}

Biji mahoni yang digunakan sebagai sampel pada penelitian ini adalah biji mahoni dari spesies Mahonia swietenia yang diperoleh dari Laboratorium Budidaya Hutan, Departemen Silvikultur, Fakultas Kehutanan IPB. Biji yang telah kering dihaluskan dengan menggunakan blender untuk memperbesar luas permukaan sampel sehingga akan dihasilkan ekstrak dalam jumlah yang optimum. Menurut Markham untuk mengekstraksi komponen aktif dari suatu jaringan tumbuhan, umumnya terlebih dahulu dilakukan penghalusan jaringan tumbuhan tersebut sebelum dilakukan ekstraksi. Hal ini dimaksudkan untuk memperluas permukaan yang akan diekstraksi. Biji mahoni halus yang diperoleh berbentuk serbuk berwarna putih kecokelatan, apabila dipegang tangan terasa berlemak dan bila tercicipi terasa pahit. Hal ini mengindikasikan bahwa biji tersebut mengandung senyawa bioaktif alkaloid. Uji sederhana untuk senyawaan alkaloid dalam daun atau buah segar adalah rasa pahitnya di lidah.

\section{Ekstraksi Senyawa Bioaktif Alkaloid}

Ekstraksi pendahuluan dilakukan untuk menghilangkan lemak yang terdapat pada biji mahohi. Hal ini dikarenakan lemak akan mengganggu proses ekstraksi lanjutan akibat terbentuknya emulsi. Petroleum benzena dipilih sebagai 
pengekstrak didasarkan pada derajat polaritas, dimana derajat polaritas bergantung pada tetapan dielektrik. Semakin besar tetapan dielektrik suatu pelarut maka kepolaran akan semakin besar. Nilai tetapan dielektrik petroleum benzene cukup rendah, yaitu 2,28 sehingga lemak akan terekstrak pada petroleum benzena. Hasil ekstraksi soxhlet dengan pelarut petroleum benzene menghasilkan ekstrak organik berupa cairan kental berwarna kuning muda.

Residu hasil ekstraksi soxhlet kemudian direfluks dengan pelarut methanol (Mursiti 2004). Pemilihan metode refluks didasarkan pada sifat sampel biji mahoni yang mempunyai tekstur keras serta komponen kimia yang akan dipisahkan tahan terhadap pemanasan. Pemilihan pelarut untuk ekstraksi menentukan komponen metabolit ektraseluler atau endoseluler yang terekstrak. Metanol digunakan sebagai larutan pengekstrak karena metanol merupakan pelarut serbaguna yang baik untuk ekstraksi pendahuluan. Penggunaan metanol sebagai larutan pengekstrak juga dikarenakan metanol memiliki dua gugus yang berbeda kepolarannya, yaitu gugus hidroksil yang bersifat polar dan gugus alkil yang bersifat non polar. Adanya kedua gugus ini diharapkan senyawa senyawa dengan tingkat kepolaran yang berbeda akan terekstrak ke dalam metanol.

Asam asetat yang ditambahkan berfungsi untuk mengekstrak alkaloid karena alkaloid bersifat basa yang disebabkan oleh adanya gugus $-\mathrm{NH}$. Penambahan asam ini menyebabkan terbentuknya garam alkaloid. Menurut Harborn, alkaloid bersifat basa lemah sehingga dapat diekstraksi dari tumbuhan dengan pelarut alkohol yang bersifat asam lemah kemudian diendapkan dengan ammonia pekat.

Larutan ekstrak kasar alkaloid selanjutnya dipekatkan menggunakan alat rotariepavorator. Penguapan dilakukan hingga seluruh pelarut menguap dan didapatkan ekstrak alkaloid yang pekat. Uji kualitatif ekstrak alkaloid dilakukan menggunakan pereaksi Dragendorff yang mengandung bismutsubnitrat dalam larutan
HCl. Hasil uji positif ditunjukkan dengan terbentuknya warna jingga pada larutan uji (Gambar 1).

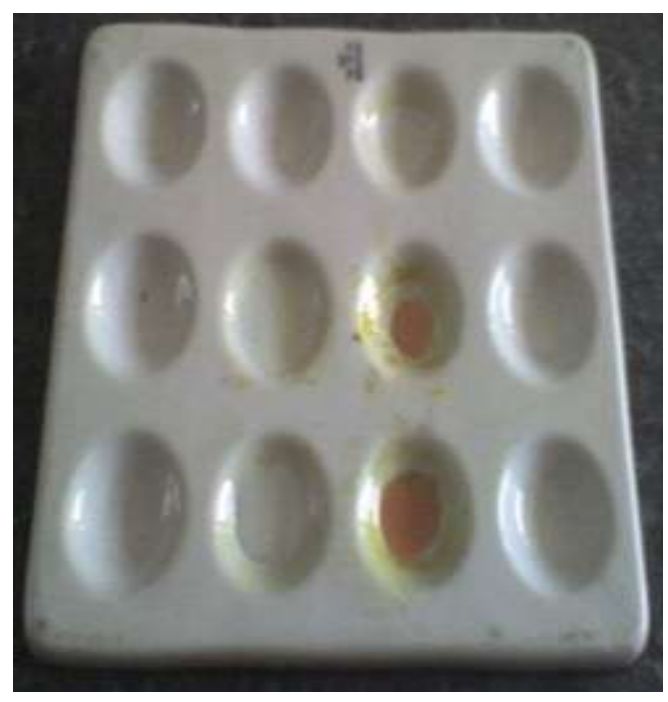

Gambar 1. Uji Kualitatif Ekstrak Akaloid Menggunakan Pereaksi Dragendorf.

\section{Hasil Analisis kromatografi}

Analisis kromatografi terhadap ekstrak kental alkaloid mahoni meliputi analisis Kromatografi Lapis Tipis (KLT) dan kromatografi kolom. Analisis KLT dilakukan untuk mengetahui berapa fraksi komponen senyawa kimia yang terdapat dalam ekstrak serta untuk optimasi eluen yang sesuai untuk kromatografi kolom. Kromatografi kolom dilakukan untuk mendapatkan fraksi tunggal yang selanjutnya akan dielusidasi struktur molekulnya.

\section{Kromatografi Lapis Tipis (KLT)}

Pelat KLT yang digunakan adalah pelat alumunium dengan adsorben silika gel F254. Visualisasi spot hasil pemisahan menggunakan lampu UV pada panjang gelombang $240 \mathrm{~nm}$. Tahap awal yang dilakukan dalam analisis KLT ini adalah optimasi pelarut.

Hasil uji KLT mengunakan pelarut kloroform:metanol dengan komposisi 75 : $25,50: 50,35: 65,25: 75$, dan $5: 95$ tidak memberikan pemisahan spot yang 
baik. Spot yang tidak terpisah dan hanya membentuk ekor ini diduga karena pelarut-pelarut pada sistem tersebut memiliki tingkat kepolaran yang berbeda dengan ekstrak (Gambar 2).

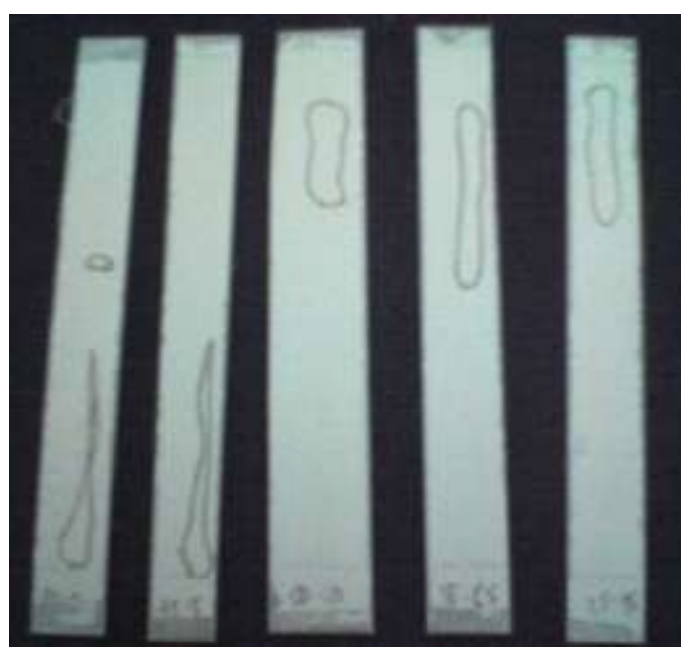

Gambar 2. Hasil Uji Optimasi Pelarut pada Kromatografi Lapis Tipis.

a. Kloroform : Metanol $=90: 10$

b. Kloroform : Metanol $=75: 25$

c. Kloroform : Metanol $=50: 50$

d. Kloroform: Metanol = $35: 65$

e. Kloroform : Metanol $=25: 75$

Hasil pemisahan terbaik ditunjukan oleh pelarut kloroform : metanol dengan komposisi 95 : 5 dan 90 : 10. Fraksi yang dihasilkan dari pemisahan dengan komposisi pelarut $90: 10$ adalah 3 sedangkan pada komposisi pelarut $95: 5$ adalah 5. Hasil uji KLT untuk kedua komposisi pelarut ini disajikan pada Gambar 3. Nilai Retardation Factor (Rf) dari masing - masing fraksi yang dihasilkan disajikan pada Tabel 1.

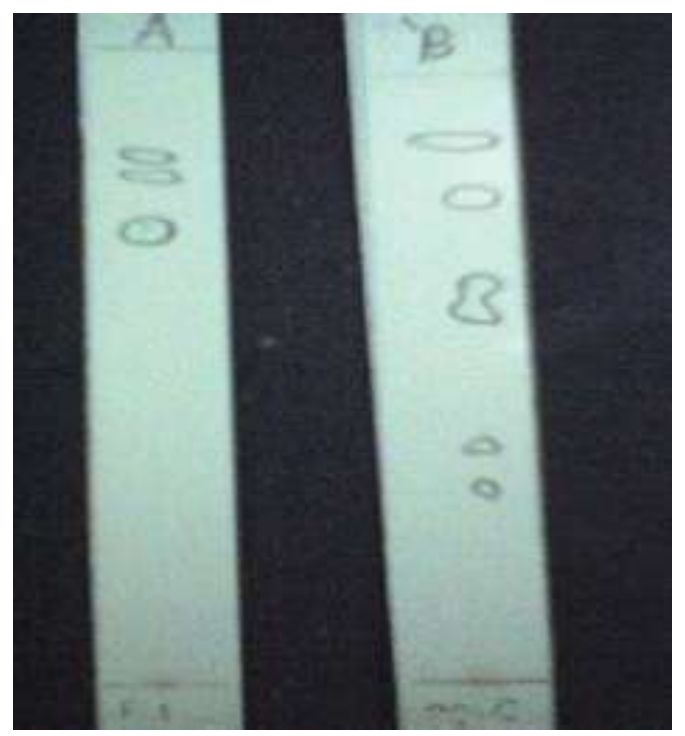

Gambar 3. Hasil Uji Optimasi Pelarut pada Kromatografi Lapis Tipis.

a. Kloroform : Metanol $=90: 10$

b. Kloroform : Metanol = $95: 5$

Tabel 1 Nilai Retardation Factor (Rf) Fraksi Hasil KLT

\begin{tabular}{lll}
\hline Jenis dan Komposisi Pelarut & Fraksi & Rf \\
\hline Kloroform:metanol = 90:10 & I & 0,82 \\
& II & 0,78 \\
& III & 0.69 \\
\hline Kloroform:metanol = 95:5 & I & 0.875 \\
& II & 0.775 \\
& III & 0.6 \\
& IV & 0.36 \\
& V & 0.30 \\
\hline
\end{tabular}


Fraksi - fraksi tersebut mempunyai nilai Rf yang berbeda - beda. Nilai Rf dapat digunakan sebagai acuan identifikasi senyawa dan menunjukan adanya perbedaan sifat molekul senyawa tersebut. Karena eluen yang digunakan cenderung semipolar, maka dapat disimpulkan bahwa urutan kepolaran senyawa dari yang lebih polar adalah fraksi III > II > I pada eluen kloroform:metanol 90 : 10. Sedangkan untuk eluen kloroform: metanol $95: 5$ urutan kepolarannya adalah fraksi V > IV > III > II > I.

\section{Kromatografi kolom}

Fraksinasi secara kromatografi kolom dilakukan terhadap ekstrak untuk mendapatkan fraksi tunggal yang akan digunakan untuk keperluan elusidasi struktur. Fraksinasi dilakukan dengan teknik gradien elusi menggunakan pereaksi n-heksan (100\%), n-Heksan : kloroform (50 : 50), kloroform:metanol (95: 5), kloroform:metanol (80 : 20). Hasil penelitian menunjukkan bahwa sampel akan turun ketika dielusi dengan menggunakan eluen kloroform:metanol (95 : 5). Hal ini sesuai dengan perlakukan sebelumnya, yaitu eluen terbaik untuk mengekstrak sampel adalah kloroform : metanol $95: 5$. Warna yang terbentuk dari hasil elusi menggunakan kloroform : metanol 95 : 5 ialah kuning dan diduga bahwa fraksi ini merupakan alkaloid.

Hasil dari kromatografi kolom ditampung dalam tabung reaksi yang terpisah dan diuji dengan KLT. Hasil visualisasi KLT dengan sinar UV pada panjang gelombang $240 \mathrm{~nm}$ menunjukan bahwa fraksi yang dihasilkan dengan eluen kloroform:metanol 95 : 5 dihasilkan satu spot (Gambar 4). Nilai Rf dari fraksi ini sebesar 0,32. Eluat dari salah satu fraksi ini selanjutnya dipekatkan kembali dengan rotarievaporator untuk keperluan elusidasi struktur molekul menggunakan instrumen UV-Vis, FT-IR, dan NMR.

\section{Elusidasi Struktur}

Spektrum UV dari ekstrak biji mahoni yang dianalisis memiliki panjang gelombang maksimum sebesar $241 \mathrm{~nm}$ dengan nilai serapan maksimum 1,2907. Hal ini disajikan pada Gambar 5. Dari Gambar 5, dapat terlihat bahwa ada peak yang melebihi batas serapan di atas 4, yaitu pada panjang gelombang $200-203,206-$ 212, dan $214-219$. Hal ini menunjukkan bahwa sampel yang dianalisis belum murni $100 \%$.

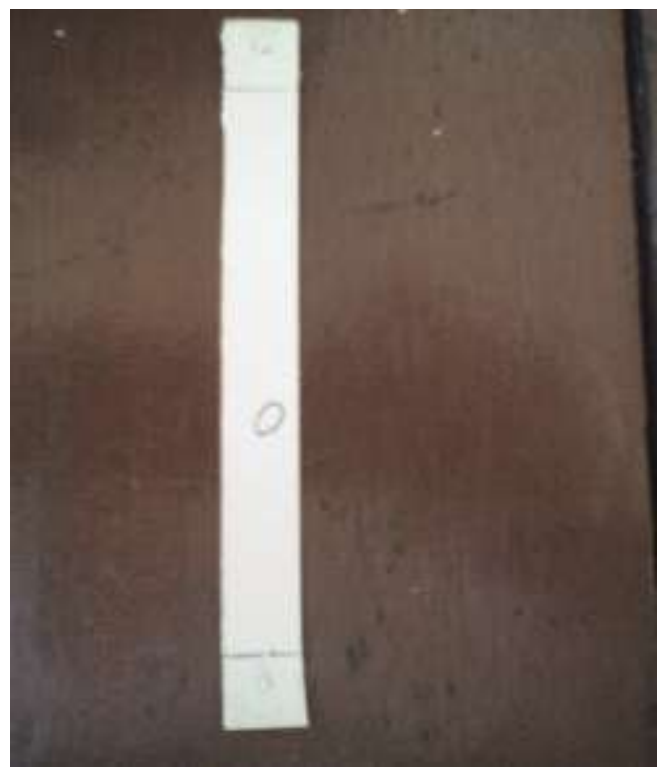

Gambar 4. Hasil uji KLT dari Faksi Hasil Kromatografi kolom.

Spektrum FTIR dari ekstrak biji mahoni (Gambar 6) memperlihatkan adanya pita serapan pada bilangan gelombang $3020 \mathrm{~cm}^{-1}$ menunjukkan adanya gugus amina sekunder (-NH). Gugus ini menegaskan bahwa senyawa tersebut merupakan golongan alkaloid. Serapan pada bilangan gelombang $1150 \mathrm{~cm}^{-1}$ menunjukkan adanya gugus $\mathrm{C}-\mathrm{O}$ eter, dan serapan pada $750 \mathrm{~cm}^{-1}$ menunjukkan adanya substituen benzena berposisi orto (Pavia DL et al. 2001).

Spektrum NMR ${ }^{1} \mathrm{H}$ dari ekstrak biji mahoni disajikan pada Gambar 7. Dari Gambar 7 tersebut dapat terlihat bahwasanya senyawa yang diidentifikasi masih mengandung pengotor. Hal ini dapat dilihat dari banyaknya peak yang memiliki tinggi kurva integrasi kurang dari 1. Dari Gambar 7 ini juga menunjukkan adanya 
beberapa gugus yang muncul, yaitu pada pergeseran kimia $(\delta)$ sebesar 7,4413 ppm menunjukkan adanya benzena. Pergeseran kimia pada 5,5505 menunjukkan adanya ikatan rangkap $(\mathrm{CH}=\mathrm{CH})$, pada 3,7281 ppm menunjukkan adanya gugus metoksi
$\left(\mathrm{CH}_{3} \mathrm{O}-\right)$, pada 2,7759 ppm menunjukkan adanya gugus R-N-H, pada 1,424 ppm menunjukkan adanya $\mathrm{R}-\mathrm{CH}_{3}$, dan pada 0,8753 ppm menunjukkan adanya $\mathrm{R}-\mathrm{CH}_{2}-$ R (Rusdi, 1988).

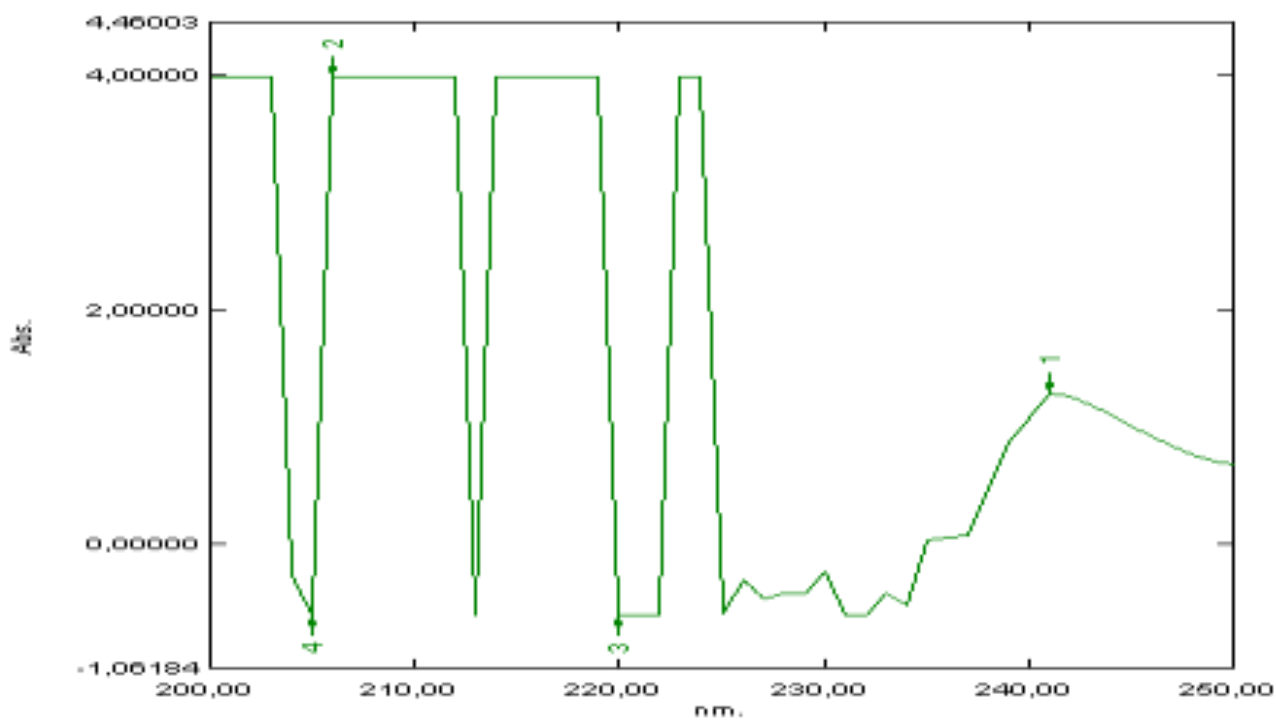

Gambar 5 Spektrum UV dari ekstrak biji mahoni.

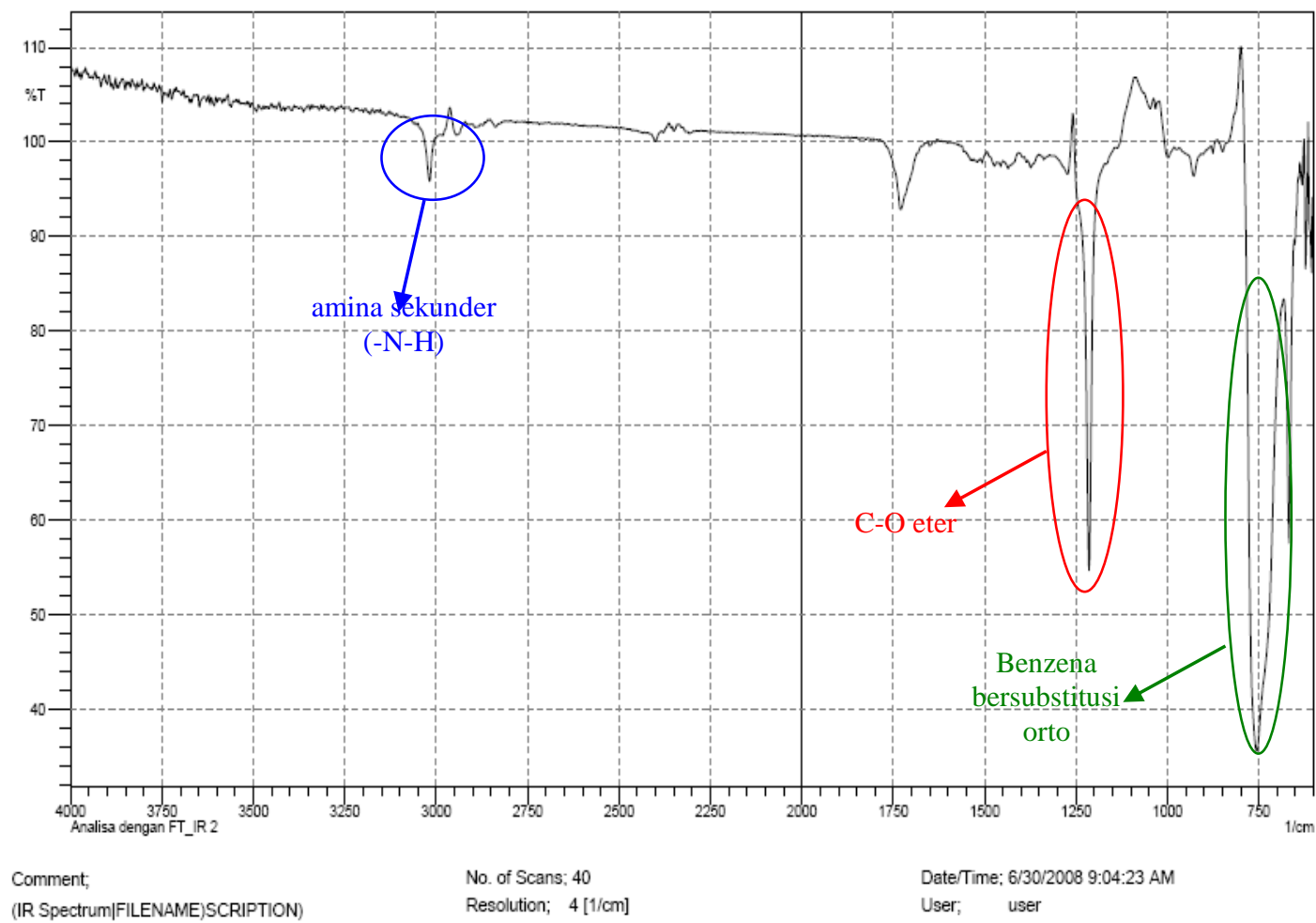

Gambar 6 Spektrum FTIR dari ekstrak biji mahoni. 
Spektrum NMR ${ }^{13} \mathrm{C}$ dari ekstrak biji mahoni disajikan pada Gambar 8. Pada pergeseran kimia 11,811 sampai 45,5419 menunjukkan adanya $-\mathrm{CH}_{3}$ atau $-\mathrm{CH}_{2}$. Spektrum ini tidak dapat membedakan antara $\mathrm{CH}_{3}$ dan $\mathrm{CH}_{2}$ karena bukan merupakan NMR ${ }^{13} \mathrm{C}$ DEPT. Pergeseran kimia pada 53,4777 dan 57,655 menunjukkan adanya C-O dan pada 139,2273 ppm serta 143,3479 ppm menunjukkan adanya karbon benzena (Gambar 8).

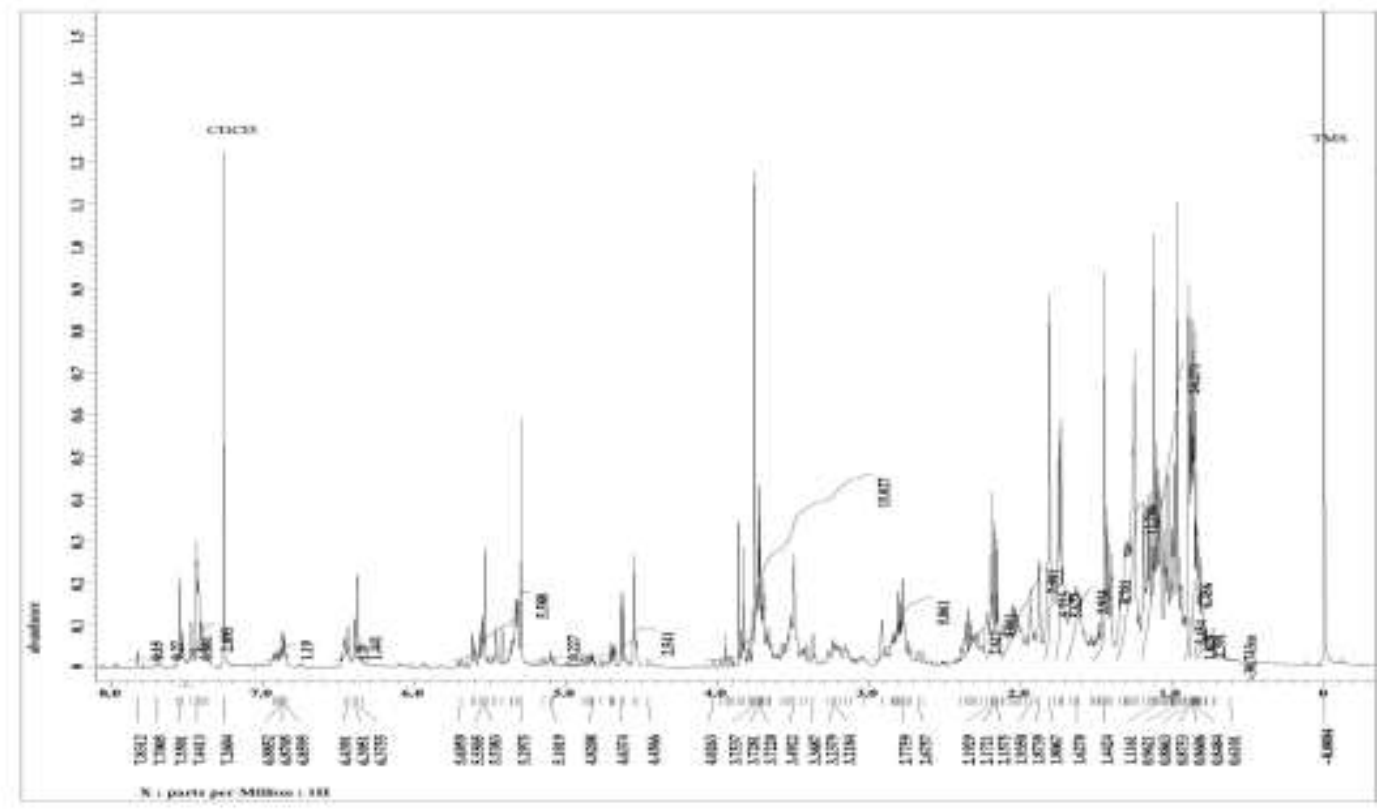

Gambar 7 Spektrum NMR ${ }^{1} \mathrm{H}$ dari ekstrak biji mahoni.

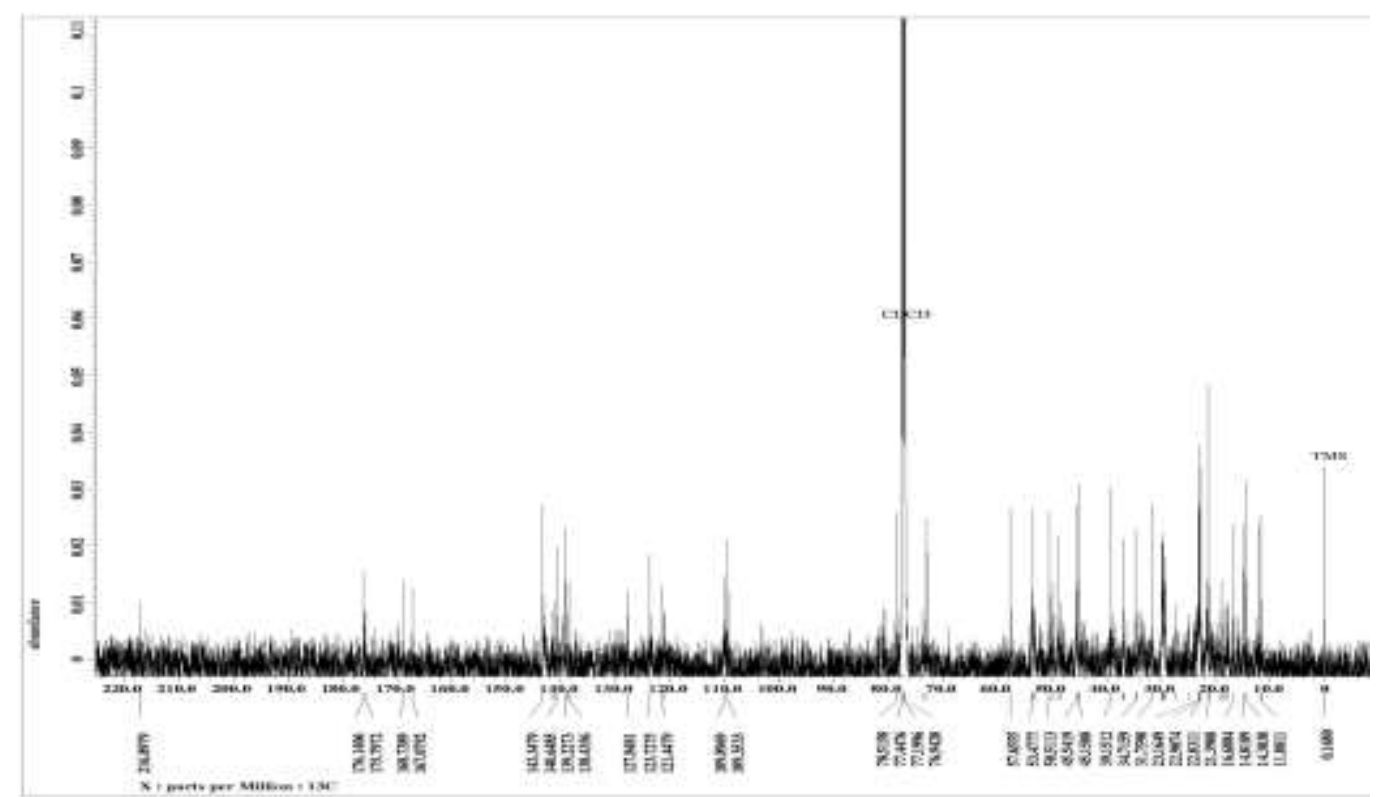

Gambar 8 Spektrum NMR ${ }^{13} \mathrm{C}$ dari ekstrak biji mahoni. 


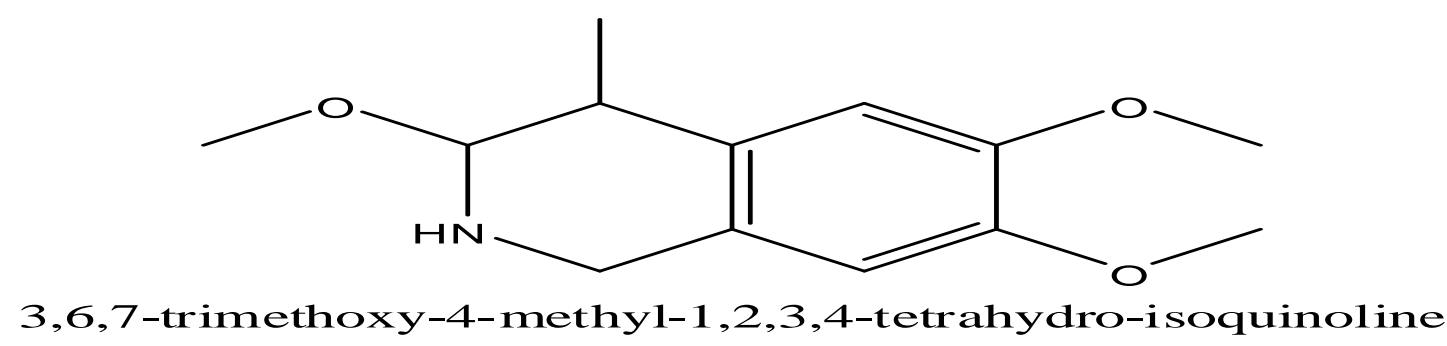

Gambar 9 Struktur dugaan dari ekstrak biji mahoni dengan asam asetat.

Menentukan struktur dari ekstrak hasil isolasi biji mahoni dari beberapa spektrum di atas tidaklah mudah. Hal ini dikarenakan ada beberapa spektrum yang memiliki pengotor yang banyak. Oleh karena itu, perlu adanya rujukan dari Dictionary of Natural Product (DNP) serta penelitian sebelumnya.

Hasil pencarian pada Dictionary of Natural Product ada beberapa senyawa yang telah ditemukan pada tanaman mahoni, yaitu berberin, 3,3',4',5,5',7hexahidroksiflavanon, isoboldin, isokoridin, isotetrandrin, Obaberine, Oxyberberine, $8 \varepsilon$-alkohol oxyberberine, $8 \varepsilon$-alkohol-8-Me ether oxyberberine, Palmatine, O3-De-Me-palmatine, 1,2,9,10Tetrahydroxyaporphine.

Hasil penelitian Mursiti menunjukkan bahwa biji mahoni bebas minyak yang diekstraksi dengan asam asetat ditemukan adanya senyawa alkaloid 3,6,7-trimetoksi-4-metil-1,2,3,4-tetrahidoisoquinolin, dengan asam sitrat ditemukan senyawa 3,4,5,6,7-pentaetil-1-metoksi- $1 \mathrm{H}$ indazol, serta dengan asam klorida ditemukan senyawa 5-etil-6-metoksimetil2-metil-1,2-dihidropiridin.

Struktur yang diduga sangat kuat pada ekstrak biji mahoni dengan asam asetat dari hasil penelitian ini adalah 3,6,7trimetoksi-4-metil-1,2,3,4 tetrahidroisokuinolin (Gambar 9). Hal ini dikarenakan struktur di atas memiliki benzena, gugus metoksi $\left(-\mathrm{OCH}_{3}\right)$, amina sekunder $(-\mathrm{N}-\mathrm{H})$, dan rantai $\mathrm{CH}_{3}-\mathrm{CH}$.

\section{KESIMPULAN}

Berdasarkan hasil uji dengan instrumen spektrofotometri UV, GC-MS, Infra red, dan NMR maka struktur yang diduga sangat kuat pada ekstrak biji mahoni dengan asam asetat adalah 3,6,7trimetoksi-4-metil-1,2,3,4 tetrahidroisokuinolin.

\section{UCAPAN TERIMAKASIH}

Ucapan terimakasih ditujukkan kepada Ibu Dr. Gustini, yang telah memberikan arahan dan bimbingan selama penelitian ini dilaksanakan.

\section{DAFTAR PUSTAKA}

Charaborty, D. P., 1980, Molecular Tzxonomy: A New Approach to Secondary Plant Constituents. In $4^{\text {th }}$ Asian Symposium on Medical Plants and Species. Departement of Chemistry, Faculty of Science, Mahidol University, Bangkok.

Dictionary of Natural Products [DNP], 2005, HDS Software copyright $($ C Hampden Data Service Ltd.

Govindachari, T. R., G. N. K. Kumari 1998, Tetranotriterpenoid from Khaya senegalensis Phytochemistry 47, 1423-1425.

Harbone, K., 1984, Metode Fitokima: Penentuan Cara Modern Menganalisis Tumbuhan. Ed. Ke2. Padmawinata K dan Soediro F, 
penerjemah, Institut Teknologi Bandung, Bandung.

Haryanti F., 2002, Isolasi senyawa antibakteri dari biji mahoni (Swietenia mahagoni Jacq.), skripsi, Institut Pertanian Bogor, Bogor.Heyne K., 1950. Denuttige Planted van Indonesian. Ed. Ke3. Gravenhage: NV Uitgeverij van Noeves.

Kardinan A., Taryono, 2003, Tanaman Obat Penggempur Kanker, Agromedia Pustaka, Jakarta.

MacKinnon S. T., Durst, J. T. Arnason 1997, Antimalarial activity of tropical Meliaceae extracts and Guidinin derivatives, Journal of Natural Product 60: 336-341.

Martawijaya et al., 1981, Atlas Kayu Indonesia Jilid I., Badan Penelitian dan Pengembangan Pertanian, Jakarta. Markam K .R., 1975, Isolation Techniques for Flavanoid, The Flavanoids Academic Press, New York.

Mulholland D. A. S., Iourine, D. A. H. Taylor, 1998, Sesquiterpenoids from Dysoxylum schiffnerri. Phytochemistry $47: 1421$ - 1422.

Mursiti. S., 2004, Indentifikasi Senyawa Alkaloid Dalam Biji Mahoni Bebas Minyak (Swietenia macrophylla KingI) Dan Efek Biji Mahoni Tehadap Penurunan Kadar Glokusa Darah Tikus Putih (Rattus Novergicus), Tesis, Universitas Gajahmada, Yogyakarta.

Nur M. A., H. Adijuwana, 1989, Teknik Spektroskopi dalam Analisis Biologis, Bogor: PAU press, Bogor.

Pavia D. L., G. M. Lampman, G. S. Kriz, 2001, Introduction to Spectroscopy : A Guide for
Students of Organic Chemistry, Thomson Learning, USA.

Putri N. E., 2004, Inhibisi fraksi aktif biji mahoni pada pertumbuhan Saccharomyces cerevisiae sebagai uji antikanker, Skripsi, Institut Pertanian Bogor, Bogor.

Robinson T., 1991, Kandungan Organik Tumbuhan Tinggi. Ed. Ke-6. Padmacwinata K, penerjemah, Institut Teknologi Bandung, Bandung.

Rusdi, 1988. Tetumbuhan sebagai Sumber Tanaman Obat, Pusat Penelitian Universitas Andalas, Padang. Schmidt L., Joker D., 2001, Swietenia mahagoni Jacq. Seed Leaflet, Danida Forest Sedd Center, Denmark.

Sianturi A. H. M., 2001, Isolasi dan fraksinasi senyawa bioaktif dari biji mahoni (Swietenia mahagoni Jacq.), Skripsi, Institut Pertanian Bogor, Bogor.

Suheti T. S. D. W., N. Kurniawan, 2007, Penjaringan senyawa antikanker pada kulit batang kayu mahoni (Swietenia mahagoni jacq.) dan uji aktivitasnya terhadap larva udang Aryemia salina leach. Jurnal Ilmiah kesehatan Keperawatan Vol.3., Universitas Jenderal Soedirman, Purwokerto.

Supriyatna, 1999, Ringkasan Kliping Berita Kesehatan. http://www.depkes.go.id/ind/new s/kliping.

Sukardiman, 2000, Isolasi dan uji sitotoksik senyawa triterpena dari kulit batang Swietenia mahagoni Jacq, Skripsi, Universitas Airlangga, Surabaya.

Syamsuhidayat S. S., J. R. Hutepea, 1991, Inventaris Tanaman Obat di Indoensia Jilid I., Badan 
Penelitian dan Pengembagan. Departemen Kesehatan Repbulik Indonesia.

Yenitta, S. Manaf dan Solfiyenni, 1999, Inventarisasi jenis - jenis tumbuhan dari famili Mytaceae, Meliaceae dan Lauraceae di kawasan Hutan Nasional Kerinci Seblat dan potensinya sebagai insektisida nabati, Tesis, Universitas Bengkulu, Bengkulu. 